\title{
Citizen Science in North American Agri-Food Systems: Lessons Learned
}

\author{
Aya H. Kimura* and Abby Kinchy ${ }^{\dagger}$
}

In April 2018, a three-day workshop entitled "Citizen Science and the Food System" took place in Honolulu, Hawai'i (USA). The ten professional scientists and six community-based investigators who participated have diverse practical experiences with citizen science (CS) covering a range of food and farming issues. This report summarizes the discussions that took place and provides suggestions to researchers, university administrators, and funding bodies on how to support agri-food research that engages a wide range of collaborators. Workshop participants shared their experiences and articulated the lessons they have learned about fostering research partnerships in the food system and the challenges that can undermine participatory research. Attention to social and historical contexts is crucial. Many aspects of the agri-food system have been built on the dispossession of indigenous peoples, and food production and distribution is highly stratified by race, ethnicity, class, and citizenship. Large corporations have significant power over the norms and practices of food production, distribution, and consumption. The pursuit of "food justice" through CS requires diligent attention to these power asymmetries and concerted efforts to redistribute power. Workshop participants also drew attention to the need for various forms of support for CS projects relating to food and agriculture. Funding is, of course, a key challenge, but academic/university expectations also hinder participatory research.

Keywords: Agriculture; food; food justice; corporate food regime; colonial relations; power; partnerships; funding

\section{Introduction}

This report summarizes the ideas exchanged at a workshop entitled "Citizen Science and the Food System," which took place at the University of Hawai'i at Mānoa on April 27-29, 2018, with the support of the National Science Foundation. The premise of the workshop was that Citizen Science (CS) can help to build knowledge of the food system that might otherwise remain unstudied or ignored. We brought together ten professional scientists and six community-based investigators who have diverse practical experiences with CS on a range of food and farming issues such as seed development, pollinators, pesticide drift, and seafood safety and conservation.

The varied outcomes of a number of CS projects were shared at the workshop, reflecting the diversity of projects in which participants were involved. Most projects led to scientific discoveries and innovations. CS projects resulted in new plant varieties for organic farming (Lyon et al. 2018); greater understanding of pollinator health (Bloom and Crowder 2020); evidence of linkage between antibiotic-resistant bacteria and livestock worker health (Guidry et al. 2018; Hatcher et al. 2017a, 2017b; Nadimpalli

\footnotetext{
* University of Hawai'i at Mānoa, US

+ Rensselaer Polytechnic Institute, US

Corresponding author: Aya H. Kimura (kimuraa@hawaii.edu)
}

et al. 2015, 2016; Rhodes et al. 2020; Rinsky et al. 2013); and documentation of pesticide drift into homes and schools (Harrison 2011, 2017; Marquez and Schafer 2017). Some projects directly helped community members to document contamination from oil sands development (Baker 2016; Baker and Fort Mackay Berry Group 2019) and from an oil spill (Simon-Friedt et al. 2016; Wickliffe et al. 2018; Wilson et al. 2015). CS also provided data that enabled citizens to avoid environmental and health harms, such as reducing exposure to heavy metals found in garden soil and collected rainwater (Ramirez-Andreotta et al. 2013, 2014, 2015; Sandhaus et al. 2018; Soleri et al. 2016). CS enhanced the scientific and health literacy of participants (Sandhaus et al. 2018). For many participants, CS fostered better relationships among researchers from universities and community members. Additionally, CS helped to demonstrate to policy makers instances where a particular issue-such as pollinator health or soil remediation-has strong public interest. In some cases, CS built participant confidence and willingness to become involved in the regulatory and policy processes needed to protect the environment and health. In at least two cases discussed during the workshop, CS results helped affected communities pursue lawsuits against polluters.

Workshop participants shared their experiences and articulated the lessons they have learned about fostering research partnerships in the food system (Figure 1). In 


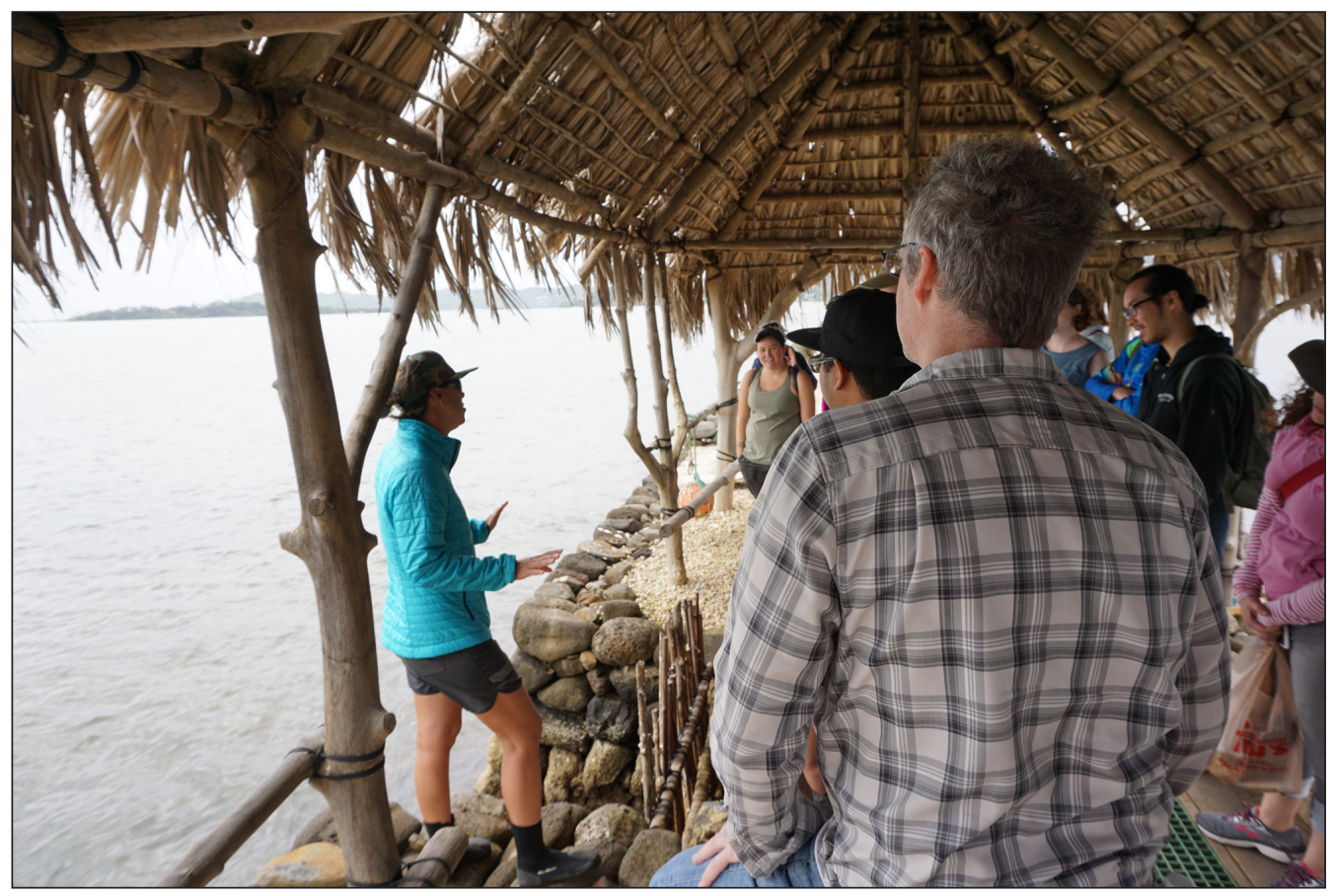

Figure 1: Workshop participants shared ideas and visited sites such as Paepae o He‘eia, a restoration project for a traditional fishpond. Photo by Aya Hirata Kimura.

this report, we summarize their discussions and provide suggestions to researchers, university administrators, and funding bodies on how to support research that engages a wide range of collaborators.

\section{Rationale and Organization of the Workshop}

There are many valid critiques of participatory research. Some critics observe that corporate or government activities that work to the detriment of the participating communities can gain legitimacy if they claim to be participatory (Peluso 1992; Ribot 1995). Another criticism is that participatory research can emphasize localism at the cost of failing to address systemic or large-scale problems (Taylor 2005). For example, the problem of climate change-induced droughts cannot be solved solely by studying local habitats. Hierarchies between organizers and lay participants also can be problematic (Cooke and Kothari 2001), and there may be power imbalances among lay participants along the lines of class, citizenship, race, and gender (Agrawal and Gibson 2001). In organizing the workshop, we recognized these critiques and based our work on the concept of food justice.

Food justice is inspired by the environmental justice movement, which has fought to promote awareness of the fact that environmental problems are embedded in societies that are racist, sexist, and lacking in support for human equality (Alkon and Agyeman 2011; Cadieux and Slocum 2015; Gottlieb and Joshi 2010; Mares and Peña 2011). Food justice recognizes that problems related to food availability and access center on questions of fairness and equality. Robert Gottlieb and Anupama Joshi described food justice as follows:

We characterize food justice as ensuring that the benefits and risks of where, what, and how food is grown and produced, transported and distributed, and accessed and eaten are shared fairly (Gottlieb and Joshi 2010).

Pursuing food justice involves multiple strategies and tactics, including participatory research. The last decade has seen a proliferation of diverse efforts to apply CS to problems associated with food and agriculture. Our survey of the literature suggests that participatory research on the food system often involves community mapping of food deserts and food access analyses (Azuma et al. 2010; Mabachi and Kimminau, 2012; Pelletier et al. 2003; Pothukuchi 2009; Sadler 2016) and monitoring of biodiversity, pests, and pathogens (Ryan et al. 2018). Other innovative uses of CS in agri-food research have included monitoring of pesticide exposures (McCauley et al. 2001). Epidemiologists have used participatory research methods for measuring the effects of industrial food production (e.g., health effects of large-scale confined hog production) (Minkler et al. 2008; Wing 2002), while ecologists have recruited citizen scientists to assist in documenting water quality decline due to agriculture (Levain et al. 2015).

While professional and academic researchers are often important partners in CS projects involving agri-food systems, nonprofit organizations are frequently the initiators of CS projects focusing on food justice. In some cases, CS is used as a strategy for social movement activists aiming to challenge the status quo. For instance, organizations concerned with pesticide drift collect air samples to monitor the flow of agrichemicals from farms to residential neighborhoods (Harrison 2011, 2017; Marquez and Schafer 2017). CS has emerged as a collective response to environmental disasters, as in the case of community reporting of seafood contamination after the British 
Petroleum (BP) oil spill (McCormick 2012). In Japan, citizen groups set up monitoring stations to check the radiation contamination levels in food and beverages after the nuclear accident in Fukushima (Kimura 2016).

Using the concept of food justice as a guide, the following key questions informed the design of the workshop and the structure of the discussions that took place:

1. How does public participation affect research agenda-setting and investigations in different areas of the food system (e.g., production, consumption, processing, waste)?

2. What is the potential for CS to advance a more holistic analysis of the agri-food system (e.g., by facilitating understanding of ecosystem impacts from seed to table to compost pile)?

3. How, and through what mechanisms, is participation in CS restricted by gender, race, and class?

4. Under what circumstances does CS operate as a type of collective action that advances a political goal for social justice and sustainability groups?

5. What institutional resources are needed to bridge CS-generated data and policy change?

The themes reflected in these questions are often interconnected, and they influenced discussion throughout the duration of the workshop. We address these questions in the workshop summary that follows. We first discuss the common challenges faced by food-system CS projects. We then share the workshop participants' advice on building strong partnerships among researchers and community members, which requires addressing power asymmetries. Finally, we discuss the kinds of institutional support that strengthen CS contributions to food justice and a sustainable food system.

\section{Challenges}

There is a growing literature on the challenges facing CS in environmental justice movements (Corburn 2005; Ottinger et al. 2016; Ottinger and Cohen 2011). Workshop participants echoed some of the known challenges while also noting the unique difficulties associated with CS projects dedicated to food justice.

\section{Corporate food regime}

Food-related CS does not exist in a vacuum and is affected by the political and economic structure in which it is embedded. Sociologist Philip McMichael has described the present-day agri-food system as a "corporate food regime" in which the power of large corporations has grown (McMichael 2005). The expansion of the corporate food regime is rooted in the deregulation of financial systems, privatization of natural resources, corporatization of agriculture, push for export-oriented production, and casualization of labor since the 1970s (Barndt 2008; Goodman and Watts 1997). While such expansion may have reduced the nominal price of food to some consumers in developed countries, it has resulted in the dispossession of peasants and the reduction of traditional farming and concomitant expansion of chemical-seed markets
(Howard 2015; Kloppenburg 2005). In many sectors, from dairy to meat processing, oligopolistic trends have intensified, with fewer and larger companies dominating the increasingly global market (Busch and Bain 2004).

CS interacts with corporate actors in both direct and subtle ways. A CS project may reveal environmental problems and strengthen the case for more stringent regulations, which can result in an industry perceiving CS as a threat to its economic bottom line and public image. This situation can lead to direct attacks on a CS project.

As an example of such an attack, in North Carolina, a CS effort with university researchers and community groups has investigated environmental and health impacts from large-scale livestock operations. The livestock industry has fiercely fought back by intimidating community members who participate in CS and by filing public records requests to obtain scientists' data (Wing 2002). One workshop participant affiliated with the research group wrote:

It is likely that our research will be placed under intense scrutiny, whether in the context of litigation or in the peer-review process. In particular, I have seen REACH [the community partner] put under a lot of pressure to perform, as industry attorneys and other critics are quick to question the quality of samples collected by what they deem to be "untrained community members," despite REACH's extensive training with [University of North Carolina/Johns Hopkins University] researchers, their participation in multiple research studies, and their extensive knowledge base. It is without a doubt that any research that is associated with social movements invokes a much greater level of external questioning of credibility compared to the other work that I am involved in. (Sarah Rhodes)

There is also a more subtle way in which the corporate food regime influences CS. Workshop participants observed that certain methods of producing food are normalized, thereby escaping scrutiny of their social and environmental impacts. Normalization makes it difficult to question the sustainability of dominant production methods, because pertinent research can be labeled "political" (hence, potentially biased). One example of this effect is farming that depends on agrochemicals and genetically modified seeds, which is the norm in North America in terms of acreage and gross sales. Daring to question the status quo by doing research into social, environmental, and health effects tends to be seen as taking a political stance. Workshop participants told us that studying and teaching alternative approaches to farming, such as agroecology and organic farming, is regarded as radical and new, even though generations of farmers have practiced such alternatives. One participant who runs a training farm wrote:

The practices that we teach and utilize are often times at loggerheads with the practices around us, and we are often criticized and/or jokingly mocked 
for our practices. We are pushed into the corner of being the ones who are deemed on a mission with political and social tones (which in truth we often are) or are just plain naive, but those farming around us are regarded (or at least regard themselves) as practicing the norm-an agriculture without political and/or social missions when, in fact, their practices are very much the tools of very specific political agendas. While many of us in our program do, in fact, have food systems change as a conscious goal, for many other participants, the decision not to utilize certain substances is as simple as wanting their children to be safely able to be in their fields and to eat the food they produce. If this is political but spraying known toxins to ... supply global agribusinesses with their patented seeds to utilize with their patented agrochemicals is not political, we find ourselves in strange times. (Jay Bost, cited in Kimura and Kinchy 2019: 20)

When critics say that such work is political, they are often trying to discredit it, suggesting it is biased and untrustworthy research.

\section{Colonial relations in agri-food systems}

Lack of access to culturally appropriate and nutritious food is a major problem that is particularly salient in indigenous communities. Colonization, forced migration, privatization of land and water, and encroachment by white settlers have critically harmed the connection between indigenous communities and their traditional food (Baker 2016; Goodyear-ka'opua 2013; Kimura and Suryanata 2016; Nabhan 2002). Industrial activities, pollution, and extraction of natural resources have reduced the availability and desirability of land, waterways, and forests and swamps, respectively impacting cultivation, fishing, and foraging.

Indigenous communities have been impacted not only by physical violence, but also by epistemological attacks that delegitimate their knowledge and normalize nonindigenous information as superior. Indigenous scholar Linda Tuhiwai Smith has written that "the methodologies and methods of research, the theories that inform them, the questions which they generate and writing styles they employ, all become significant acts which need to be considered carefully and critically before being applied. In other words, they need to be "decolonized'" (Smith 2005: 41).

CS, when practiced by, or in deep collaboration with, indigenous communities may start to address power asymmetries. However, drawing on their work with indigenous communities, some workshop participants pointed out that the power asymmetry between credentialed scientists in Western academia and indigenous communities is still a real problem in CS. For instance, anthropologist Janelle Marie Baker has worked with the Fort McKay First Nation in Canada, which started community-based monitoring of berries driven by concerns with contamination from oil sands development. She observed that, despite the "community-based" mantra of the project,
non-Aboriginal project partners tend to take control of the project. She wrote:

Most of all, the concern I have had from the beginning of this project is the use of science to prove or disprove Fort McKay participants' observations and how the scientific results from this project could be (mis)used by government and industry to publicly demonstrate that the oil sands industrial activities are having 'no significant impacts' on First Nations' traditional lands or health.... Underlying the abovedescribed and often subtle tensions is systemic racism in Canada toward Aboriginal peoples.... This means that even well-meaning scientists ... often assume that the First Nations' project members are not able to manage their own research funds or projects, and that First Nations no longer possess or practice their traditional knowledge, even though it is easily observable in the region. Ultimately, settlers on these projects are sometimes blind to the rich spiritually based environmental knowledge that community members share and enact for survival and systems of respect and reciprocity on the land (cited in Kimura and Kinchy 2019: 16).

Agri-food CS involving indigenous participants must recognize the spiritual, social, and cultural values associated with wildlife, food, and crops (Kagawa-Viviani et al. 2018). There is increasing pressure to claim intellectual property over germplasm, which may counter indigenous beliefs. For instance, declarations such as the Treaty for a Lifeforms Patent-Free Pacific (1995) and the Paoakalani Declaration (2003) in Hawai'i embody the rejection of privatization of lifeforms from indigenous perspectives.

Similar cultural tensions have been reported in the broader literature on biological conservation and indigenous people. Martin et al. (2016) point out that the Nagoya Protocol for the Convention on Biological Diversity focuses more on the distributive aspects of justice than on recognition. A project might have nominal participation by indigenous members but still perpetuate recognition injustice by marginalizing indigenous knowledge and imposing Western frames of understanding.

\section{Misalignment of expectations and priorities}

Professional researchers in a wide range of fields, from plant breeding to nutrition to environmental toxicology, have an interest in studying food and agriculture in partnership with affected communities. Community- and nongovernment organization (NGO)based workshop participants emphasized the need for basic political education for researchers with respect to their positionality and the need for reflexivity. University researchers are highly educated and are immersed in a specific institutional culture of higher education and academic science. One scientist said:

[You need] to understand power, your own power as a researcher. We all have power that moves in different ways. Understanding about race, class 
and the power and privilege of the role of the university that works through you. And to understand the institutional biases that are built in. To be able to get outside of your comfort zone. If you don't have the training to talk to people, [you won't] have the skills to then be able to have the capacity to have real conversations. [You should be] learning how to listen to community members, really listen for a long time.

Another scientist added: "This is not the space where you should be the dominant voice. In academia, we are told that we are the experts ... and you are dictating science "down" to lay people....You need to understand that universities are historically actors that are not trusted in the community." This statement reflects awareness that scientific research institutions have a fraught history of treating ethnic minorities, indigenous peoples, and others in an unethical manner.

Because of social distance and power disparities, researchers and community members may not realize that they bring different expectations to a CS project. Workshop participants emphasized the importance of good communication before the initiation of a project. There should be agreement on the following questions: What are the desired outcomes, who is to be involved, what resources are expected from each party, and how and when are results shared?

While in some cases volunteers may prioritize social change goals (e.g., making agriculture more sustainable, improving health), others may be motivated mainly by the desire to learn about an issue. In the latter situation, volunteers may be unwilling to commit to a project for the long term.

Workshop participants debated how to address this conflict in priorities. One proposed idea was to simplify projects so that volunteers are able to make a contribution while gaining the knowledge they seek. In response, it was suggested that simplifying the research task might lower the stakes for volunteers and diminish their commitment to the project. When volunteers do not have uniform reasons for joining a project, it is important to consider the range of motivations. This can be accomplished by forming a stakeholder advisory group to represent the different interest groups engaged in the project. The advisory group can meet to determine priorities and shared interests.

If volunteers are intrinsically interested in making socio-environmental change, project leaders need to design the program accordingly-building the volunteers' sense of efficacy and confidence. This means establishing projects with clear normative goals, fostering volunteer commitment to those goals, and allowing research to develop from that collaboration.

Misalignment of expectations also can develop when study results do not confirm a community's perceptions. Often, community groups contact university researchers when they suspect environmental contamination. They may hope to get hard data on pollution and contamination that can help them press for both policy and corporate behavioral changes. However, test results may be negative or fall within regulatory thresholds. Several workshop participants described how partnerships with community groups were challenged when there was a finding of no significant impact (e.g., air pollution is at "safe" levels, suspicions of food contamination are unconfirmed). Often, when no significant hazards are found, the research is interpreted as suggesting that there is no problem and that the community's concerns are unwarranted. For community partners, this conclusion may come as a relief, but it also can be demoralizing, because the community's personal experience is not validated as a possible hazard.

In one example, researchers emphasized that even though their study did not confirm the community's suspicions that its fisheries were polluted, there were limitations on the study, and the community lacked funding to pursue subsequent questions. One of the lead researchers explained:

When we found out there was nothing in the shrimp, [the lead scientist] was specific that it is only about the shrimp that we trawled in these areas at a specific time. This doesn't speak to consumption levels. FDA set the consumption levels, assuming that you eat a quarter pound. They were curious about if you eat 5 pounds. They wanted to look at genotoxicity, if it changes over time. There was a whole list of other types of fish that consumers were concerned about.... You start to answer but then you can't get the funding to answer the rest of the question.

Workshop participants stressed that a negative finding can result from a narrow framing of the problem. Addressing patterns of exposure that concern residents might require a wider variety of collaborators and additional research questions. Through multidisciplinary research, collaborators can expand the conversation to identify which questions should be asked and who should be involved in addressing community concerns.

\section{Credibility challenges}

In CS, data collected by nonprofessionals may attract scrutiny. The workshop participants reported persistent prejudice against data produced by volunteers, even with the help of credentialed scientists. They shared stories of struggling to establish the legitimacy of their data and their interpretations.

Members of a community participating in a study, given that they are not trained scientists, may have difficulty defending the technical aspects of a CS project. As an example, the Pesticide Action Network of North America (PANNA) uses devices called Drift Catchers to monitor pesticide drift. PANNA uses a reference exposure level (REL) that is based on the California Office of Environmental Health Hazard Assessment (OEHHA) framework, rather than the REL of the federal EPA. Because pesticides are applied in areas where children reside, PANNA prefers to use the OEHHA calculation of REL, which is designed for sensitive populations, such as children or pregnant women, 
and is based on the breathing rates and body weight of children. However, the findings of PANNA's partner organizations have been dismissed when results do not exceed the federal EPA REL, which is higher. While PANNA feels that it can justify its use of the OEHHA REL, a workshop participant from the organization said "it can be extremely challenging for community members and project partners to defend this highly technical component of the analysis, even with PANNA scientists testifying in support."

The credibility problem of CS is particularly salient when CS involves community members who represent explicit advocacy and policy change goals. In the CS literature, several articles have been published which raised concerns of conflict of interest in advocacy-oriented CS. These articles argue that when the goal of citizen scientists is "to advance their political objectives" (Nature 2015), or to form "alliances with private, nonprofit, and political organizations, as well as their involvement in lawsuits" (Guerrini et al. 2018), such CS projects are at serious risk of conflict of interest. However, the workshop participants pointed out that politically minded community members do not necessarily "corrupt" science, and typically they produce valid scientific data. Participants discussed how CS volunteers and organizers actually spent considerable resources and time on increasing the validity of their data.

Participant Monica Ramírez-Andreotta shared that she does extensive training of volunteers. She wrote, "I'm exceedingly careful because I knew if we observed a contaminant of concern at an elevated concentration, one of the first things others might want to challenge is the methodology; they'd say, 'Oh, they did not know how to collect the samples." She noted that the skeptical view of volunteer-driven data is rooted in the false assumption that experts exclusively possess the ability to generate valid data. She wrote, "In my experience, participants follow protocols, demand accuracy and precision in me and themselves, and want answers that will inform whether they need to modify their behavior to reduce exposure" (cited in Kimura and Kinchy 2019: 12).

\section{Data-sharing conflicts}

The process of sharing data and findings was an important topic for discussion during the workshop. If an academic researcher is expected to publish results before publicizing them, this may limit sharing of key information with affected communities. One researcher observed: "I operate under the philosophy that if it's something that's not good, you act on it immediately. I contact people immediately ... [In contrast,] I have colleagues that are like no way am I reporting anything before I publish it."

Some researchers advocated creating a "team charter" or "memorandum of understanding" between the lead scientist(s) and the other participants in the project. ${ }^{1}$ These documents may include commitments to get people the help they need if the study shows that they have been exposed to a health risk. For example, in one study that involved biomarker work, the researchers developed a plan to report any findings of high blood levels to the affected research participant.
Participants summarized the following best practices for sharing information: ${ }^{2}$

- Discuss different possible findings with community partners and develop a "team charter" regarding action on each possible circumstance.

- Immediately share very alarming preliminary findings with the research participants while investigating further.

- Share findings with health workers, the project's advisory committee, and other internal reviewers for feedback.

- De-identify findings in publications.

- Make sure that community partners have the resources and/or support needed to utilize the findings as they see fit.

\section{Outcome: Practical Lessons on Building Partnerships}

A key theme of the workshop was building partnerships among community organizations and scientific institutions such as universities. Participants agreed that it is essential to make time to discuss the needs of all involved in a project and to deepen relationships. They compiled their advice to those seeking to develop a collaborative CS project. Their recommendations overlap with existing best practices, some of which are cited here, but they are rooted in the experience of the workshop participants' own successes and frustrations. The scope of this paper does not attempt to tease out how implementing these recommendations would improve the outcomes of CS, but we encourage future studies to explore how these recommendations materialize in actual CS cases. ${ }^{3}$

\section{Perform preliminary research}

It is essential for project organizers to have a clear understanding of the historical context in which the communitybased research (CBR) might take place. Organizers should survey the issues and consult with those with strong ties to the community. Power relationships among the participants and collaborators and the institutional environment should be mapped out. For example, researchers should investigate the social context of the issue, examining who has been impacted negatively and who has benefited from the status quo.

\section{Recognize the value of social researchers}

Agri-food issues intersect with social marginality, colonialism, and concentration of economic power. Any individual researcher or community organizer is not going to possess all the skills required to fully examine every dimension of the agri-food issue. One of the suggestions made by workshop participants is to expand interdisciplinary collaboration to include social scientists. Many CS projects already have natural scientists on board, but not necessarily anthropologists, sociologists, or political scientists. However, social scientists who have expertise in agri-food politics and environmental justice help CS organizers become aware of the previously discussed complex social dynamics associated with the agri-food system. 


\section{Consult existing guidelines and principles}

Workshop participants directed attention to existing guidelines for developing equitable relationships between professional scientists and community groups. These guidelines include the Nine Principles of Community-Based Participatory Research (CBPR) (Israel et al. 1998), which provides some foundations, and the Jemez Principles for Democratic and Inclusive Organizing (Jemez Principles for Democratic Organizing n.d.). The key guidelines follow:

- Be inclusive

- Emphasize bottom-up organizing

- Let people speak for themselves

- Work together in solidarity and mutuality

- Build just relationships among ourselves (project participants)

- Commit to self-transformation

\section{Set clear normative goals}

Organizers should establish the type of research to be done and the reasons why the research is necessary. Project goals and intended outcomes should always be discussed with all partners before the project begins. (e.g., climate change resilience, food security, children's health). An evaluation of the proposed research should be made to ensure that it can achieve set goals.

\section{Build a relationship of trust and respect before seeking funding}

Relationship-building can take a year or more. The process should begin by collaborating with other researchers who are personally known and trustworthy, then branching out to include other partners. Researchers from outside the community should show up in service, as volunteering is a good way to build authentic personal relationships. The leadership of people from the affected communities should be followed.

\section{Develop good meeting practices}

Meeting dynamics are important to building equitable and trusting partnerships. It is important to seek the opinions of community organizers and to show them deference without assuming superior knowledge. Anyone who attends a meeting should be viewed as an equal participant, regardless of social status or title. All meeting attendees should be allowed the opportunity to speak for a set amount of time to establish an atmosphere of inclusiveness.

Meetings should be scheduled to accommodate those with caregiver responsibilities, and childcare should be provided. Culturally appropriate food should be offered to people making time to attend meetings. Gatherings where participants are made to feel comfortable and can converse in their native languages should be hosted. It can be beneficial to seek the support of older community members who are retired and have time to devote to community projects while remaining mindful of the needs of older adults.

\section{Create an agreement on information sharing}

Before beginning a project, it is essential to create fair agreements that cover ownership of data, co-authorship, and other products generated by the project. University researchers should discuss with their employers details on the kinds of data and research that they plan to pursue and how it may be perceived. Community organizers should be prepared for scrutiny of the data and, therefore, must clearly inform community partners that there may be pushback.

\section{Anticipate the possibility of confidential findings}

Community partners might not want research results to be published or publicized. This could occur if the findings stand to threaten the value of their properties or livelihoods. There are also considerations regarding what to publicize if no significant results (e.g., no finding of food contamination) are discovered. While a community may be relieved that it has not been exposed to a contaminant, there may be situations where it prefers that such a result remain confidential. This could happen, for instance, if a community is involved in a legal dispute and the data weakens its claims. These are issues that should be discussed and agreed upon before the start of the project.

\section{Value participants' time and efforts}

Participants in a CS project may be volunteers, but their efforts should be compensated whenever possible. For example, a local NGO could be hired to serve as liaison, coordinate aspects of outreach, and write community workers into budgets. Even when funding is not available, other forms of collaboration can help to maintain the relationship with the community. For example, university professors can provide informal education, and environmental organizations can support communities with needed public policy information.

\section{Outcome: Identified Needs for Institutional Support}

Workshop participants focused attention on the need for various forms of support for CS projects relating to food and agriculture. Funding is, of course, a key challenge, but academic/university expectations also hinder participatory research.

\section{University-level support}

There is a growing interest in articulating the steps that institutions can take to encourage effective and ethical CS beyond simply recognizing the need for promotion of CS. The workshop identified both promotional and additional needs for institutional support. For instance, the League of European Research Universities' report, "Citizen Science at Universities" (2016), includes several recommendations for universities, such as recognizing CS as a valid research method, creating a single point of contact for CS on campus, and raising awareness of good practices of CS among faculty members.

Workshop participants from North America concurred that research universities do not always accept participatory practices toward research expectations and identified 
the critical need for institutional change that is conducive to fostering long-term community partnerships. In addition to its societal benefits, universities need to recognize CS as a valid research methodology. One of the mechanisms that can be further leveraged is extension services. Land-grant universities have extension services whose mission is to bring practical information to farmers (Ryan et al. 2018).

Recognition of the value of CS needs to be incorporated into tenure and promotion criteria. One participant commented, "There needs to be something done among the institutions to make this more acceptable in terms of advancement. Otherwise, people will always go for the grant projects and the research projects that help them towards tenure."

Shifting the culture and expectations of universities requires changes in the mindset of faculty members as well as administrators. Faculty can take an active role in reviewing grants and directing funding toward CS projects, as well as advocating for collaborative and community-based research on campuses, to normalize this type of research.

\section{Scarcity of resources for developing partnerships}

Participants described the obstacles to spending sufficient time building relationships in their communities. Academic researchers described how their teaching, research, and committee work interfered with devoting time to collaborate with community partners.

Some workshop participants had found solutions to these obstacles. One participant had written educational grants that enabled him to pay a local NGO to serve as a liaison. A liaison helps to coordinate outreach, taking some responsibilities off a faculty member's plate. Likewise, another researcher wrote funded community health worker positions into grants and created a subcontract with a local NGO.

However, the structure of the grant cycle, and the inflexibility of grants and other funding sources, can hinder the work of building relationships. One scholar noted that grants often do not support the time needed for people to collaboratively plan how they are going to spend the money. Because relationships with community partners should be strong before a grant application is submitted, community-based project planning must be completed before a proposal is written. Some participants noted that without prior grant support, it is extremely difficult to allocate time to building critical community relationships.

Additionally, participants who rely on grants commented that they require stable funding to maintain projects over the long term. Grants often are awarded for new and innovative practices, but ongoing partnerships are more difficult to fund.

Workshop participants identified the following ways in which funding bodies can better support CS projects:

- Seed grants. Professional researchers should meet with community partners to discuss research ideas before going forward with a grant proposal; this requires a longer timeframe for developing a proposal for community-driven research. Thus, seed grants are needed to build relationships and explore the many dimensions of the project prior to pursuing funding for collaborative research. These grants should allow for the possibility that the seed project will not lead to further collaboration if it does not foster a relationship with community partners.

- Flexible spending. Grants should allow flexibility in allocating funds to those items prioritized by participants. Priorities often change throughout the research process and cannot be determined before the funding period begins.

- Multistage funding. Funders should create ways for grantees to apply for further funding to investigate additional problems discovered during the first stage of research.

\section{Misalignment of grants with seasonal practices}

Seasonality is a challenge when working with farmers or when working outdoors. Seasonality does not align well with timeframes for grants. Some participants described their seasonal research and its effect on the availability of participants. Planning and funding participatory projects must take seasonality into account. One researcher described a government-funded project that was logistically challenging: "We'll wait around for the government funding to come through. One year there was a fire in the community, where we had to evacuate a lot of people, so we were only able to do one research trip when we usually do three. In Canada, if you don't use all of your funds then they'll cut them the following year. The logistics are intense, especially with the snow."

Another researcher noted, "It's like a joke for farmers. 'There's a three-week window [when I'm available to participate]. It's right after elk hunting season." In other words, collaboration with farmers can be challenging, because they are committed to activities that are fundamentally tied to seasonal cycles.

With these seasonal impact factors in mind, participants made the following recommendations:
- Flexible spending and reporting deadlines. Funding programs should be more flexible and allow exten- sions when more time is needed or when an opportu- nity to pursue another area of interest arises.
- Application deadlines that reflect seasonal cycles. Funders should carefully consider the timing of grant application and reporting deadlines with respect to potential timing conflicts for participants. Seasonal cycles are particularly relevant to grants for agricul- tural and land-based projects.

\section{Conclusions}

Public participation affects research agenda-setting and investigations in different areas of the food system. CS already has produced scientific data (e.g., data on pesticide drift, soil contamination) and new resources (e.g., new vegetable varieties). CS also can foster better relationships between academic researchers and community groups and can increase interest in health and environmental issues among volunteers. 
CS has the potential to advance more holistic analysis of the agri-food system, and many investigators recognize the need for multidisciplinary research efforts. These include attention to social and historical contexts. Many aspects of the agri-food system have been built on the dispossession of indigenous peoples, and food production and distribution are highly stratified by race, ethnicity, class, and citizenship. Large corporations have significant power over the norms and practices of food production, distribution, and consumption. The pursuit of "food justice" through CS requires diligent attention to these power asymmetries and concerted efforts to redistribute power.

CS can sometimes operate as a kind of collective action for social justice and sustainability groups, helping to bring about structural change in the food system. However, commitment to normative goals sometimes comes into conflict with scientists' perceived professional obligations to remain neutral. The implicit judgement that activist-oriented CS is inherently biased and unscientific works against efforts to address existing inequity and injustice. In some instances, CS has been valuable in bringing about policy changes affecting agri-food systems. However, significantly greater institutional resources are needed if CS-generated data are to live up to their potential for informing policy changes. The ideas and recommendations summarized in this workshop report should support efforts to grow the transformative impacts of participatory research in the ecological and social systems that feed us.

\section{Notes}

${ }^{1}$ There are useful online resources for those seeking to create a team charter. See the Public Health Foundation's Team Charter and related toolkits (http://www. phf.org/resourcestools/Pages/Team_Charter.aspx).

2 Readers seeking more guidance on this matter are advised to consult the following report from the Silent Spring Institute: When Pollution is Personal: Handbook for Reporting Results to Participants in Biomonitoring and Personal Exposure Studies (https://silentspring. org/personal_exposure_report_handbook.pdf).

${ }^{3}$ Those seeking more formal guidance on building community-institutional partnerships may wish to consult the curriculum developed by the Community-Institutional Partnerships for Prevention Research Group, funded by the Centers for Disease Control. Developing and Sustaining CBPR Partnerships: A Skill Building Curriculum (http://depts.washington.edu/ccph/cbpr/ index.php).

\section{Ethics and Consent}

All workshop participants have reviewed and approved publication of this text.

\section{Acknowledgements}

The authors wish to thank the students, Alex Balgos, Benjamin Schrager, Jonathan Valdez, and Maricate Mangan, who assisted with organization of the workshop and provided research assistance. We especially thank all of the following workshop participants for the generosity of their time and enthusiasm and for their collabora- tion and exchange of ideas: Janelle Marie Baker, Jay Bost, 'Qátuẃas (Jessica Brown), Catherine Chan, David Crowder, Robert Gottlieb, Devon Hall, Sr., Alice Hall, Jill Harrison, Marcia Ishii-Eiteman, Albie Miles, James Myers, Daniel Nguyen, Mónica Ramírez-Andreotta, Sarah Rhodes, and Jeffrey Wickliffe.

\section{Funding Information}

The workshop was supported by the U. S. National Science Foundation (Award \#1743138).

\section{Competing Interests}

The authors have no competing interests to declare.

\section{Author Contributions}

The authors contributed equally to the development of the workshop and the writing of this report. Due to proximity, Kimura was primarily responsible for local workshop logistics and supervising student assistants, while Kinchy took the lead in preparing written workshop materials and facilitating discussions among participants. The authors worked collaboratively to analyze the extensive notes and recordings from the workshop to write this report.

\section{References}

Agrawal, A and Gibson, C. 2001. Communities and the Environment: Ethnicity, Gender, and the State in Community-Based Conservation. New Brunswick: Rutgers University Press.

Alkon, AH and Agyeman, J. 2011. Cultivating Food Justice: Race, Class, and Sustainability. Cambridge, MA: MIT Press. DOI: https://doi.org/10.7551/mitpress/8922.001.0001

Azuma, AM, Gilliland, S, Vallianatos, M, et al. 2010. Food Access, Availability, and Affordability in 3 Los Angeles Communities, Project CAFE, 2004-2006. Preventing Chronic Disease, 7(2): A27.

Baker, JM. 2016. Research as Reciprocity: Northern Cree Community-Based and Community-Engaged Research on Wild Food Contamination in Alberta's Oil Sands Region. Engaged Scholar Journal: Community-Engaged Research, Teaching, and Learning, 2(1): 109-124. Available at: https://journalhosting.ucalgary.ca/index.php/esj/article/view/61481 (accessed 15 February 2019).

Baker, JM and Fort Mackay Berry Group. 2019. Cranberries are Medicine: Monitoring, Sharing, and Consuming Cranberries in Fort McKay. In: Johnson, LM (ed.) Traditional Knowledge for Northern Community Well-Being. Edmonton: University of Alberta Press.

Barndt, D. 2008. Tangled Routes: Women, Work, and Globalization on the Tomato Trail. Lanham: Rowman \& Littlefield.

Bloom, EH and Crowder, DW. 2020. Promoting data collection in pollinator citizen science projects. Citizen Science: Theory and Practice, 4: X. 1-12. DOI: https://doi.org/10.5334/cstp.217

Busch, L and Bain, C. 2004. New! Improved? The Transformation of the Global Agrifood System. 
Rural Sociology, 69: 321-346. DOI: https://doi. org/10.1526/0036011041730527

Cadieux, KV and Slocum, R. 2015. What does it mean to do food justice. Journal of Political Ecology, 22: 1-26. DOI: https://doi.org/10.2458/v22i1.21076

Cooke, B and Kothari, U. 2001. Participation: The New Tyranny? London: Zed Books.

Corburn, J. 2005. Street Science: Community Knowledge and Environmental Health Justice. Cambridge, MA: MIT Press. DOI: https://doi.org/10.7551/mitpress/6494.001.0001

Goodman, D and Watts, M. 1997. Globalising Food. London and New York: Routledge.

Goodyear-ka'opua, N. 2013. The Seeds We Planted: Portraits of a Native Hawaiian Charter School. Minneapolis: University of Minnesota Press. DOI: https://doi.org/10.5749/minnesota/9780816680474. 001.0001

Gottlieb, R and Joshi, A. 2010. Food Justice. Cambridge, MA: MIT Press. DOI: https://doi. org/10.7551/mitpress/7826.001.0001

Guerrini, CJ, Majumder, MA, Lewellyn, MJ, et al. 2018. Citizen science, public policy. Science, 361(6398): 134-136. DOI: https://doi.org/10.1126/ science.aar8379

Guidry, VT, Rhodes, SM, Woods, CG, et al. 2018. Connecting Environmental Justice and Community Health Effects of Hog Production in North Carolina. North Carolina Medical Journal, 324-328. Available at: http://www.ncmedicaljournal.com/content/79/5/324.short (accessed 15 February 2019). DOI: https://doi.org/10.18043/ncm.79.5.324

Harrison, JL. 2011. Pesticide Drift and the Pursuit of Environmental Justice. Cambridge, MA: MIT Press. DOI: https://doi.org/10.7551/mitpress/9780262015981.001.0001

Harrison, JL. 2017. Taking a Different Tack. In: The New Food Activism: Opposition, Cooperation, and Collective Action, 31-54. Berkeley: University of California Press. DOI: https://doi.org/10.1525/california/9780520292130.003.0002

Hatcher, SM, Rhodes, SM, Stewart, JR, et al. 2017a. The Prevalence of Antibiotic-Resistant Staphylococcus aureus Nasal Carriage among Industrial Hog Operation Workers, Community Residents, and Children Living in Their Households: North Carolina, USA. Environmental Health Perspectives, 125(4): 560-569. DOI: https://doi. org/10.1289/EHP35

Hatcher, SM, Rhodes, SM, Stewart, JR, et al. 2017b. The Prevalence of Antibiotic-Resistant Staphylococcus aureus Nasal Carriage among Industrial Hog Operation Workers, Community Residents, and Children Living in Their Households: North Carolina, USA. Environmental Health Perspectives, 125(4): 560-569. DOI: https:// doi.org/10.1289/EHP35

Howard, PH. 2015. Intellectual Property and Consolidation in the Seed Industry. Crop Science, 55(6): 2489-2495. DOI: https://doi.org/10.2135/ cropsci2014.09.0669
Israel, B, Schulz, A, Parker, E, et al. 1998. Review of community based research: assessing partnership approaches to improve public health. Annual Review of Public Health, 19: 173-202. DOI: https://doi. org/10.1146/annurev.publhealth.19.1.173

Jemez Principles for Democratic Organizing. (n.d.). Available at: http://www.ejnet.org/ej/jemez.pdf.

Kagawa-Viviani, A, Levin, P, Johnston, E, et al. 2018. I ke ēwe 'āina o ke kupuna: Hawaiian Ancestral crops in Perspective. Sustainability, 10(12): 4607. DOI: https://doi.org/10.3390/su 10124607

Kimura, AH. 2016. Radiation Brain Moms and Citizen Scientists: The Gender Politics of Food Contamination after Fukushima. Durham, NC: Duke University Press. DOI: https://doi.org/10.1007/s10460-017-9791-y

Kimura, AH and Kinchy, A. 2019. Citizen Science in Agri-Food Systems: Lessons and Recommendations. Report on the outcomes of a workshop at the University of Hawai'i-Mānoa, April 27-29, 2018, supported by the National Science Foundation (Award \#1743138). Available at: https://sih.berkeley.edu/research-project/citizen-science-in-agri-food-systems-lessons-andrecommendations/.

Kimura, AH and Suryanata, K. 2016. Food and Power in Hawai' $i$ : Visions of Food Democracy. Honolulu: University of Hawaii Press. DOI: https://doi. org/10.21313/hawaii/9780824858537.001.0001

Kloppenburg, J. 2005. First the Seed: The Political Economy of Plant Biotechnology. Madison: University of Wisconsin Press.

League of European Research Universities. 2016. Citizen science at universities: Trends, guidelines and recommendations. Advice Paper 20. Available at: https://www.leru.org/files/Citizen-Science-at-Universities-Trends-Guidelines-and-RecommendationsFull-paper.pdf.

Levain, A, Vertès, F, Ruiz, L, et al. 2015. 'I am an Intensive Guy': The Possibility and Conditions of Reconciliation Through the Ecological Intensification Framework. Environmental Management; New York, 56(5): 1184-1198. DOI: https://doi.org/10.1007/s00267-015-0548-3

Lyon, A, Tracy, W, Colley, M, et al. 2018. Adaptability analysis in a participatory variety trial of organic vegetable crops. Renewable Agriculture and Food Systems, 1-17. DOI: https://doi.org/10.1017/ S1742170518000583

Mabachi, NM and Kimminau, KS. 2012. Leveraging Community-Academic Partnerships to Improve Healthy Food Access in an Urban, Kansas City, Kansas, Community. Progress in Community Health Partnerships-Research Education and Action, 6(3): 279-288. DOI: https://doi.org/10.1353/cpr.2012.0046

Mares, TM and Peña, DG. 2011. Environmental and food justice: toward local, slow and deep food systems. In: Alkon, AH and Agyeman, J (eds.), 197-219. Cambridge, MA: MIT Press.

Marquez, EC and Schafer, KS. 2017. Kids on the Frontline How pesticides are undermining the health of rural children. Oakland: PANNA. Available at: http://www. panna.org/resources/kids-frontline. 
Martin, A, Coolsaet, B, Corbera, E, et al. 2016. Justice and conservation: the need to incorporate recognition. Biological Conservation, 197: 254-26. DOI: https:// doi.org/10.1016/j.biocon.2016.03.021

McCauley, LA, Beltran, M, Phillips, J, et al. 2001. The Oregon migrant farmworker community: an evolving model for participatory research. Environmental Health Perspectives, 109(Suppl 3): 449-455. DOI: https://doi. org/10.1289/ehp.01109s3449

McCormick, S. 2012. After the Cap: Risk Assessment, Citizen Science and Disaster Recovery. Ecology and Society, 17(4): 31. DOI: https://doi.org/10.5751/ ES-05263-170431

McMichael, P. 2005. Global Development and The Corporate Food Regime. Research in Rural Sociology and Development, 11: 265-299. DOI: https://doi. org/10.1016/S1057-1922(05)11010-5

Minkler, M, Vásquez, VB, Tajik, M, et al. 2008. Promoting Environmental Justice Through Community-Based Participatory Research: The Role of Community and Partnership Capacity. Health Education \& Behavior, 35(1): 119-137. DOI: https://doi. org/10.1177/1090198106287692

Nabhan, GP. 2002. Coming Home to Eat: The Pleasures and Politics of Local Foods. New York: WW Norton \& Company.

Nadimpalli, M, Rinsky, J, Wing, S, et al. 2015. Persistence of livestock-associated antibiotic-resistant Staphylococcus aureus among industrial hog operation workers in North Carolina over 14 days. Occupational Environmental Medicine, 90-99. DOI: https://doi. org/10.1136/oemed-2014-102095

Nadimpalli, M, Stewart, JR, Pierce, E, et al. 2016. Livestock-Associated, Antibiotic-Resistant Staphylococcus aureus Nasal Carriage and Recent Skin and Soft Tissue Infection among Industrial Hog Operation Workers. PLOS ONE, 11(11): e0165713. DOI: https://doi. org/10.1371/journal.pone.0165713

Nature. 2015. Rise of the citizen scientist, 524(7565): 265. DOI: https://doi.org/10.1038/524265a

Ottinger, G, Barandiaran, $\mathbf{B}$ and Kimura, $\mathbf{A H}$. 2016. Environmental justice: knowledge, technology, and expertise. In: Miller, CL, Felt, U, Fouché, $\mathrm{R}$ and Smith-Doerr, L (eds.), Handbook of Science and Technology Studies, 1029-1058. 4th Edition. Cambridge, MA: MIT Press.

Ottinger, G and Cohen, B. (eds.) 2011. Technoscience and Environmental Justice: Expert Cultures in a Grassroots Movement. Cambridge, MA: MIT Press. DOI: https:// doi.org/10.7551/mitpress/9780262015790.001.0001

Pelletier, D, McCullum, C, Kraak, V, et al. 2003. Participation, power and beliefs shape local food and nutrition policy. Journal of Nutrition, 133(1): 301S-304S. DOI: https://doi.org/10.1093/jn/133.1.301S

Peluso, NL. 1992. Rich Forests, Poor People: Resource Control and Resistance in Java. Berkeley and Los Angeles: University of California Press. DOI: https://doi. org/10.1525/california/9780520073777.001.0001

Pothukuchi, K. 2009. Community and Regional Food Planning: Building Institutional Support in the United
States. International Planning Studies, 14(4): 349367. DOI: https://doi.org/10.1080/135634710036 42902

Ramirez-Andreotta, M, Brusseau, ML, Artiola, JF, Maier, RM and Gandolfi, AJ. 2014. Environmental research translation: Enhancing interactions with communities at contaminated sites. Science of the Total Environment, 497: 651-664. DOI: https://doi. org/10.1016/j.scitotenv.2014.08.021

Ramirez-Andreotta, $\mathbf{M}$, Brusseau, ML, Beamer, $\mathbf{P}$ and Maier, RM. 2013. Home gardening near a mining site in an arsenic-endemic region of Arizona: Assessing arsenic exposure dose and risk via ingestion of home garden vegetables. Science of the Total Environment, 454: 373-382. DOI: https://doi.org/10.1016/j.scitotenv.2013.02.063

Ramirez-Andreotta, MD, Brusseau, ML, Maier, RM, et al. 2015. Building a co-created citizen science program with gardeners neighboring a superfund site: The Gardenroots case study. International Public Health, 7(1): 1-18.

Rhodes, S, Brown, K, Cooper, L, et al. 2020. Environmental Racism in North Carolina's Hog Industry: Lessons-learned from Community-Driven Participatory Research and the People's Professor. In: Mah, A and Davies, T (eds.), Environmental Justice and Citizen Science in a Post-Truth Age. Manchester: Manchester University Press.

Ribot, J. 1995. From exclusion to participation: Turning Senegal's forestry policy around? World Development, 23(9): 1587-1599. DOI: https://doi. org/10.1016/0305-750X(95)00060-P

Rinsky, JL, Nadimpalli, M, Wing, S, et al. (2013) Livestock-Associated Methicillin and Multidrug Resistant Staphylococcus aureus Is Present among Industrial, Not Antibiotic-Free Livestock Operation Workers in North Carolina. Plos One, 8(7): e67641. DOI: https:// doi.org/10.1371/journal.pone.0067641

Ryan, SF, Adamson, NL, Aktipis, A, et al. 2018. The role of citizen science in addressing grand challenges in food and agriculture research. Proceedings of the Royal Society B: Biological Sciences, 285(1891): 20181977. DOI: https://doi.org/10.1098/rspb.2018.1977

Sadler, RC. 2016. Integrating expert knowledge in a GIS to optimize siting decisions for small-scale healthy food retail interventions. International Journal of Health Geographics, 15: 19. DOI: https://doi.org/10.1186/ s12942-016-0048-6

Sandhaus, S, Kaufmann, D and Ramirez-Andreotta, M. 2018. Public participation, trust and data sharing: gardens as hubs for citizen science and environmental health literacy efforts. International Journal of Science Education, Part B, 1-18. DOI: https://doi.org/10.1080/ 21548455.2018.1542752

Simon-Friedt, BR, Howard, JL and Wilson, MJ. 2016 Louisiana residents' self-reported lack of information following the Deepwater Horizon oil spill: Effects on seafood consumption and risk perception. Journal of Environmental Management, 180: 526-537. DOI: https://doi.org/10.1016/j.jenvman.2016.05.030 
Smith, LT. 2005. Decolonizing Methodologies: Research and Indigenous Peoples. London: Zed Books.

Soleri, D, Long, JW, Ramirez-Andreotta, MD, et al. 2016. Finding Pathways to More Equitable and Meaningful Public-Scientist Partnerships. Citizen Science: Theory and Practice, 1(1): 1-11. DOI: https://doi. org/10.5334/cstp.46

Taylor, PJ. 2005. Unruly Complexity: Ecology, Interpretation, Engagement. Chicago: University of Chicago Press. DOI: https://doi.org/10.7208/chicago/9780226790398.001.0001

Wickliffe, JK, Simon-Friedt, B, Howard, JL, et al. 2018. Consumption of Fish and Shrimp from Southeast Louisiana Poses No Unacceptable Lifetime Cancer
Risks Attributable to High-Priority Polycyclic Aromatic Hydrocarbons. Risk Analysis, 38(9): 1944-1961. DOI: https://doi.org/10.1111/risa.12985

Wilson, MJ, Frickel, S, Nguyen, D, et al. 2015. A Targeted Health Risk Assessment Following the Deepwater Horizon Oil Spill: Polycyclic Aromatic Hydrocarbon Exposure in Vietnamese-American Shrimp Consumers. Environmental Health Perspectives, 123(2): 152-159. DOI: https://doi. org/10.1289/ehp.1408684

Wing, S. 2002. Social responsibility and research ethics in community-driven studies of industrialized hog production. Environmental Health Perspectives, 110(5): 437-444. DOI: https://doi.org/10.1289/ehp.02110437

How to cite this article: Kimura, AH and Kinchy, A. 2020. Citizen Science in North American Agri-Food Systems: Lessons Learned. Citizen Science: Theory and Practice, 5(1): 4, pp. 1-12. DOl: https://doi.org/10.5334/cstp.246

Submitted: 15 April $2019 \quad$ Accepted: 05 November $2019 \quad$ Published: 07 February 2020

Copyright: (c) 2020 The Author(s). This is an open-access article distributed under the terms of the Creative Commons Attribution 4.0 International License (CC-BY 4.0), which permits unrestricted use, distribution, and reproduction in any medium, provided the original author and source are credited. See https://creativecommons.org/licenses/by/4.0/.

] $\mathbf{u}[\quad$ Citizen Science: Theory and Practice is a peer-reviewed open access journal published by Ubiquity Press. 